OPEN ACCESS

Edited by:

Ana Claudia Zenclussen, University Hospital

Magdeburg, Germany

Reviewed by:

Aylin Carla Hanyaloglu,

Imperial College London,

United Kingdom

Kenneth Beaman,

Rosalind Franklin University of Medicine and Science, United States

Philip Savage,

Royal Sussex County Hospital, United Kingdom

*Correspondence:

Virginie Gridelet

virginie.gridelet@uliege.be

Specialty section: This article was submitted to Immunological Tolerance and

Regulation,

a section of the journal

Frontiers in Immunology

Received: 06 October 2019

Accepted: 12 February 2020

Published: 13 March 2020

Citation:

Gridelet V, Perrier d'Hauterive $S$,

Polese B, Foidart J-M, Nisolle $M$ and Geenen V (2020) Human Chorionic Gonadotrophin: New Pleiotropic

Functions for an "Old" Hormone During Pregnancy.

Front. Immunol. 11:343. doi: 10.3389/fimmu.2020.00343

\section{Human Chorionic Gonadotrophin: New Pleiotropic Functions for an "Old" Hormone During Pregnancy}

\author{
Virginie Gridelet ${ }^{1,2 *}$, Sophie Perrier d'Hauterive ${ }^{1,2}$, Barbara Polese ${ }^{1}$, Jean-Michel Foidart ${ }^{3}$, \\ Michelle Nisolle ${ }^{2,4}$ and Vincent Geenen ${ }^{1}$ \\ ${ }^{1}$ GIGA-I3 Center of Immunoendocrinology GIGA Research Institute, University of Liege, Liege, Belgium, ${ }^{2}$ Center for Assisted \\ Medical Procreation, University of Liège, CHR Citadelle, Liège, Belgium, ${ }^{3}$ Laboratory of Tumor and Development Biology, \\ University of Liège, Liège, Belgium, ${ }^{4}$ Department of Obstetrics and Gynecology, CHR Citadelle, University of Liège, Liège, \\ Belgium
}

Human chorionic gonadotrophin ( $\mathrm{hCG}$ ) is the first specific molecule synthesized by the embryo. hCG RNA is transcribed as early as the eight-cell stage, and the blastocyst produces the protein before its implantation. hCG in the uterine microenvironment binds with its cognate receptor, luteinizing hormone/choriogonadotropin receptor (LHCGR), on the endometrial surface. This binding stimulates leukemia inhibitory factor (LIF) production and inhibits interleukin-6 (IL-6) production by epithelial cells of the endometrium. These effects ensure essential help in the preparation of the endometrium for initial embryo implantation. hCG also effects angiogenic and immunomodulatory actions as reported in many articles by our laboratories and other ones. By stimulating angiogenesis and vasculogenesis, hCG provides the placenta with an adequate maternal blood supply and optimal embryo nutrition during the invasion of the uterine endometrium. The immunomodulatory properties of hCG are numerous and important for programming maternal immune tolerance toward the embryo. The reported effects of hCG on uterine NK, Treg, and B cells, three major cell populations for the maintenance of pregnancy, demonstrate the role of this embryonic signal as a crucial immune regulator in the course of pregnancy. Human embryo rejection for hCG-related immunological reasons has been studied in different ways, and a sufficient dose of hCG seems to be necessary to maintain maternal tolerance. Different teams have studied the addition of hCG in patients suffering from recurrent miscarriages or implantation failures. hCG could also have a beneficial or a negative impact on autoimmune diseases during pregnancy. In this review, we will discuss the immunological impacts of hCG during pregnancy and if this hormone might be used therapeutically.

Keywords: hCG, implantation, pregnancy, immunology, miscarriages, autoimmunity

\section{INTRODUCTION}

In its first days of development, the trophoblast secretes an important hormone: the chorionic gonadotrophic hormone (hCG). hCG is going to have a series of actions in the survival of the embryo, the best known of which is progesterone secretion maintenance by the corpus luteum (1).

hCG is a glycoprotein hormone of $36-40 \mathrm{kDa}$. It is composed of two subunits, $\alpha$ and $\beta$, linked with a noncovalent bond. The $\alpha$ subunit, composed of 92 amino acids, is encoded in chromosome 
6 and is common in various hormones of the glycoprotein family including luteinizing hormone ( $\mathrm{LH})$, thyroid-stimulating hormone (TSH), and thyroid-stimulating hormone (TSH). The $\beta$ subunit, which is different for each hormone, is encoded on different genes on chromosome 19 (LH, hCG, and TSH) or on chromosome 11 (FSH). The $\beta$ subunit of hCG is encoded in six different but very similar genes located in a group of genes on chromosome 19 (2). The $\beta$ subunit of hCG is, with 145 , the $\beta$ subunit with the highest number of amino acids but also the largest glycosylated domain. This gives the hCG greater stability and facilitates its rapid secretion. Unlike other glycoprotein hormones that are synthesized by the anterior lobe of the pituitary gland, hCG is not only produced by the trophoblast (and mainly by the syncytiotrophoblast) but also by malignant tumors. hCG contains four N-linked oligosaccharides and four O-linked oligosaccharides.

hCG's structure is similar to that of LH, but unlike LH, hCG exists in several forms, known as classical hCG, hyperglycosylated hCG, and the free $\beta$ unit of hyperglycosylated hCG (3). Each of these four molecules has different physiological functions. Chorionic gonadotropins only exist in primates (in humans, this is hCG) and in equines (named eCG for equine CG). In mice, LH could play the same role as hCG and is secreted early by the embryo (4).

\section{hCG ISOFORMS}

In addition to conventional hCG, there is a highly glycosylated hCG variant, which is hyperglycosylated hCG (hCG-H). Its $\beta$ subunit has four oligosaccharide-linked Os instead of two in classical hCG (5). This variant is massively produced during the first trimester of pregnancy by the extravillous cytotrophoblasts, the form of hCG that is the most massively present during the very beginning of pregnancy. It represents $87 \%$ of the total hCG in the third week of gestation and $51 \%$ during the fourth week. Then, it decreases rapidly until it completely disappears from the maternal blood circulation at the end of the first trimester (6). hCG-H is known to have an autocrine action rather than an endocrine action, decreasing the apoptosis of trophoblast cells (7) and inducing the implantation of the embryo (8) and trophoblastic invasion (9). It is also massively secreted by choriocarcinomas and germ cell tumors $(5,9,10)$. A team suggested recently that hCG-H is functionally similar to hCG, although it has lower potency for luteinizing hormone/choriogonadotropin receptor (LHCGR) activation (11). This result is controversial with other results but not impossible $(12,13)$. hCG-H might act through different receptors.

hCG-H monitoring is useful for predicting Down's syndrome (9), preeclampsia (14), therapeutic response to trophoblastic diseases, and pregnancy predictions performed in in vitro fertilization (15).

The free $\beta$ subunit of hCG would also act like an antagonist through the transforming growth factor beta (TGF- $\beta$ ) receptor $(16,17)$ and is enabled to activate LHCGR $(11)$. Like hCG-H, this subunit would have a promotive action on cancer.
The sulfated hCG produced by the pituitary gland is hardly detectable during the menstrual cycle. It is secreted in parallel with LH during the cycle and is concentrated at approximately one-fifth of the LH concentration (18-20). While these levels are low, sulfated hCG is exactly 50 times more potent than LH (21). Thus, sulfated hCG could perform comparable work with LH in stimulating androstenedione production during the follicular phase of the cycle as well as stimulating ovulation and corpus luteum formation. During the luteal phase, it may help stimulate progesterone production (18-21).

\section{hCG SECRETION}

hCG is one of the first molecules secreted by the embryo. Its RNA is transcribed as early as the eight-cell stage (22), and the blastocyst produces the protein before implantation $(23,24)$. The syncytiotrophoblast highly produces this hormone after implantation (25). Significant concentrations of hCG can already be measured in the maternal blood 10 days after ovulation. hCG concentration reaches its peak during the first trimester of pregnancy. It occurs around the 10th of gestation and can be measured 75,000 IU/L. Afterwards, the level decreases gradually to the 19th week. Its remains basal until the end of the pregnancy, $\sim 15,000 \mathrm{IU} / \mathrm{L}$. This rate remains higher than in nonpregnant women $(26,27)$. It has been recently shown that during in vitro fertilization (IVF) treatments, faster-growing blastocysts produced significantly higher serum $\beta$-hCG concentrations 9 days after transfer than slower-growing blastocysts in fresh cycles, but the difference was not significant by day 16 after transfer (28).

Macrophages can regulate excess hCG, known to have teratogenic effects on fetal tissues. Human fetal tissue macrophages are proposed to incorporate and destroy hCG in a time-dependent manner, which protects fetal gonadogenesis from the deleterious effects of hCG (29, 30). Specifically, Katabuchi and his team have recently shown that hCG induces the formation of vacuoles in human monocytes. With these vacuoles, they look like fetal Hofbauer cells. They hypothesize that Hofbauer cells, and more particularly their vacuoles, would be involved in the protection of fetal tissues against unusually high concentrations of hCG (31).

Abnormalities in the production and the circulating levels of the several glycoforms of hCG throughout specific periods of gestation and in the relative variations have been associated with a large array of pregnancy complications, such as miscarriages (32), fetal chromosomal anomalies (33), preeclampsia (34, 35), disturbances in fetal growth and development (36), and gestational trophoblastic diseases (37). The serum $\beta$-hCG level predicts biochemical/clinical pregnancy and singleton/multiple pregnancy with robust sensitivity and specificity (38).

Emerging evidence suggests that prenatal exposure to selected endocrine disrupting chemicals (EDCs) have a deleterious impact on the fetus and long-lasting consequences in adult life as well. Several reports have shown that in vitro effects of commonly found EDCs, particularly bisphenol A and para-nonylphenol, can alter hCG production, and through this action, it might exert their fetal damage [reviewed by Paulesu et al. (39)]. 
hCG (or its alpha subunit or beta subunit) is also secreted by gestational trophoblastic neoplasia. It includes malignant invasive mole, choriocarcinoma, and rare placental site trophoblastic and epithelioid tumors (40). hCG can be found in testicular cancer. Gestational choriocarcinoma and testicular cancer have been routinely curable for over 50 years and have cure rates approaching 95 and $85 \%$, respectively. In contrast, hCG production by cancers, aside from these two types, is generally associated with a worsening of the prognosis, like in lung, liver, or ovary cancers $(41,42)$. Immunization to hCG in experimental models has been shown to have antitumor effects (43-45).

\section{hCG ACTIONS}

In 1920, Hirose showed a hormonal link between a hormone produced by the placenta and the production of progesterone by corpus luteum's cells $(3,46)$. This hormone has been called gonadotropic chorionic hormone. Stimulation of progesterone production by the corpus luteum has long been the only known function of hCG (Figure 1). This hormone induces also the upregulation of aromatase expression and estradiol production in human granulosa lutein cells. This effect might be mediate by amphiregulin (47). hCG strongly stimulates the expression of its own receptor in human luteal cells (48).

Three independent teams have shown that the preimplantation blastocyst secretes hCG into the uterine space that will bind to its LHCGR receptor on the deciduous surface. In response, the decidua prepare for implantation (49-51). The stromal cells undergo the decidualization under the effect of hCG, after which they secrete prolactin (52). hCG also increases the secretion of leukemia inhibitory factor (LIF) and decreases the secretion of interleukin-6 (IL-6) by endometrial cells, molecules known for their influence on embryo implantation (50). It promotes the differentiation of cytotrophoblasts into syncytiotrophoblasts (53), and it can regulate prostaglandin synthesis (54) and the formation of cyclic AMP (cAMP) (55). A study has shown that different forms of hCG might stimulate trophoblastic invasion independently of the classical hCG receptor, LHCGR (56). The glycosylation of hormones has a direct influence on their bioactivity. Hyperglycosylated hCG would be more beneficial than conventional hCG for the implantation (8). Further studies are required to clarify whether this hCG-H effect on endometrial stromal cells involves LHCGR or TGF $\beta$ receptor (TGF $\beta R$ ) or both (57).

hCG also has angiogenic actions as discussed in two papers from our laboratory $(58,59)$. hCG increases blood vessel formation and the migration and maturation of pericytes in different in vitro and in vivo models (60-63). It also has a positive impact on the secretion of vascular endothelial growth factor (VEGF), a well-known molecule of angiogenesis (60, 64). Recently, a study has shown that hCG regulates VEGF through the activation of nuclear factor kappa B (NF-кB) in luteal angiogenesis (65). hCG has protective effects on vascular endothelial cells against oxidative stress through inhibition of apoptosis, activation of cell survival signaling, and mitochondrial function retention (66).

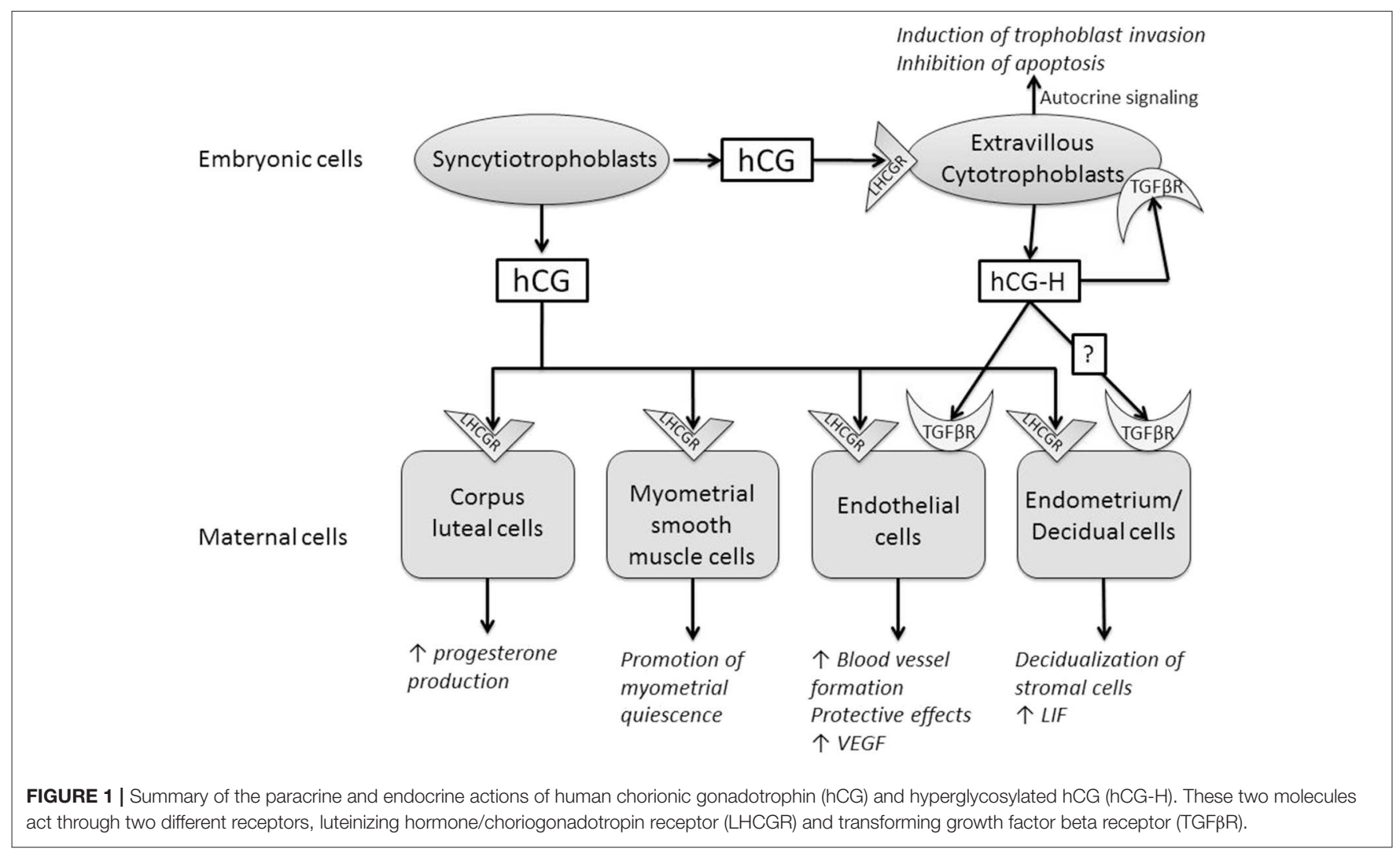


hCG-H also displays a potent angiogenic effect. However, hCG-H induces angiogenesis regardless of LHCGR signaling pathways $(13,67)$. The antiapoptotic action of hCG-H would also be achieved independently of LHCGR. The specific receptor(s) activated by hCG-H on trophoblasts cells and, potentially, on various decidual cells has/have not been fully identified (57). Berndt et al. demonstrated that hCG-H displayed a potent angiogenic effect by interacting with TGF $\beta$ R (more precisely TGF $\beta$ RII). They eliminated the angiogenic effect of hCG-H by the addition of SB431542n, the antibody against TGF $\beta$ RII, in the culture medium of their model. It was confirmed in LHCGR-knockout mice (13). Several groups implicated hCG-H in promoting growth and invasion of placental and germ cell malignancies through the TGF- $\beta$ signaling pathway by utilizing potential autocrine interactions $(17,68)$. Structural similarity between hCG-H and TGF $\beta$ supported this idea of interaction between hCG-H and TGFßRII. They share a unique fourpeptide cysteine knot structure identified in several cytokines that collectively form the cysteine knot growth factor family $(67,69,70)$. Interestingly, a study reported a woman with an inactive mutant LHCGR who maintained a normal pregnancy after becoming pregnant with ovum donation. This suggest that the maintenance of pregnancy through LHCGR activation is not unavoidable and that, during pregnancy, the main hCG effect may be mediated by other mechanisms than LHCGR activation (71).

The team of Gallardo has suggested that the striking overlapping of hCG and Heme oxygenase-1 (HO-1) functions in pregnancy could indicate that hCG hormonal effects are mediated by HO-1 activity, which may be affected by a HMOX1 polymorphism in humans (72). HO-1 regulates angiogenesis and vasculogenesis, and trophoblasts proliferation, migration, and invasion, thus contributing to the adaptive changes in the uterine circulation to pregnancy.

hCG and hCG-H are therefore considered proangiogene molecules. By stimulating angiogenesis and vasculogenesis, they allow the placenta to have adequate maternal blood supply during functional endometrial invasion and optimal fetal nutrition.

A study investigated the effects of different doses of hCG on hCG receptor-immunoreactive neuron density in the prefrontal cortex and cerebellum of a rat model of stretozotocin-induced Alzheimer's disease (73). hCG administration resulted in a significant dose-dependent increase in the number of hCG receptor-ir neurons in the prefrontal cortex and cerebellum (74). The same group showed that hCG attenuates amyloid- $\beta$ plaques induced by streptozotocin in the rat brain by affecting cytochrome c-ir neuron density (75). They conclude that hCG might be useful in patient with Alzheimer's disease to prevent the congophilic $A \beta$ plaque formation and decrease cytochrome c-immunoreactive neuron density in the brain.

\section{IMMUNOLOGICAL ACTIONS OF hCG}

The immunomodulatory properties of hCG are numerous and important for maternal tolerance of the embryo (59). The activation of the maternal immune system tolerance appears essential for the embryonic development and the implantation (76).

CD4+ $\mathrm{T}$ cells can be classified into the following subsets: $\mathrm{T}$ helper (Th) 1, Th2, Th17, and regulatory cells $\mathrm{T}$ (Treg) according to their functions. One study indicated that immunity in patients suffering with recurrent miscarriages is dominated by the Th1/Th2 hypothesis (77). However, the Th1/Th2 paradigm alone is not enough to explain the mechanism by which the fetus is rejected by maternal immune cells. The Th1/Th2 paradigm has been extended to the Th1/Th2/Th17 and Treg cell paradigm. Th17 cells and Treg have been described as lymphocyte subsets that are different from Th1 and Th2 cells. These are known to play a major role in the development of autoimmune diseases and infection. Previous studies have shown that Th17/Treg imbalance can be associated with recurrent spontaneous abortion $(78,79)$. While most studies show that hCG has a suppressive effect on T-cell proliferation (80), trophic effects of hCG have also been reported (81). Evidence exists of a potential intersection between the hCG and the $\mathrm{T}$ cell receptor (TCR) signal. In a contradictory manner, hCG encourages trophoblast invasion and interstitial theca cell proliferation by overmodulating extracellular-regulated kinase (ERK) and AKT signals (82, 83); leptin production by hCG requires a dialogue between cAMP and p38 signaling pathways in the syncytiotrophoblast (84). Gestational trophoblastic neoplasias strongly express programmed cell death ligand 1 (PD-L1), a protein expressed by $\mathrm{T}$ cells activated. The team from Ghorani describes the curative treatment of women with chemotherapy refractory choriocarcinoma with Pembrolizumab (PD1 immunotherapy) (40). This paper shows the impact that removal of $\mathrm{T}$ cell regulation has on the interface between $\mathrm{T}$ cell and trophoblast cells and further strengthens the debate regarding the immunosupressive pregnancy environment in part resulting from hCG.

Furthermore, hCG has different effects on CD4+ T cells. During the 1970s, it was suggested that hCG might have an effect on maternal lymphocytes (85). Since then, it has been shown that hCG has a positive impact on the proliferation of $\mathrm{CD} 4+25+\mathrm{T}$ cells and that it attracts these cells to the endometrium in early pregnancy $(86,87)$. Immune cells located at the implantation site actively contribute to embryo implantation $(88,89)$. hCG increases the frequency of murine Treg cells in vivo and decreases their suppressive activity in vitro (90).

hCG increases the presence of regulatory $\mathrm{T}$ cells and increases the level of IL-1beta in mice (91). This hormone appears to play a key role as a tolerance modulator during pregnancy (90). A recent study shows that hCG inhibits the expression of CD25 and CD28 on the surface of naive $\mathrm{T}$ cells (CD45RA+) and the expression of CD25 on memory $\mathrm{T}$ cells (CD45R0+). Apparently, hCG promotes the differentiation of memory $\mathrm{T}$ cells by increasing the expression of CD45R0+ but reduces their functional activity toward fetal antigens through a competitive process. hCG also increases the production of IL-2 by naive and memory T cells. This hormone is therefore involved in the regulation of these $\mathrm{T}$ cells (92). 
By modulating the balance between inflammatory-type Th1 cells and anti-inflammatory-type Th2, the hCG plays a fundamental role in the implantation of the embryo $(59,93)$.

hCG has a positive impact on uterine natural killer (uNK) cells, important leukocyte cells in the nongestating uterus that act on the establishment and maintenance of embryo implantation in women and mice (94-96). hCG regulates the proliferation of uNKs (97) in a dose-dependent manner in vitro (98). These cells do not express LHCGR, and hCG would act directly on these cells through another receptor, mannose receptor (98), which is expressed by the uNK. uNKs participate in the remodeling of spiral arteries, a crucial vascular modification for the vascularization of the placenta, which guarantees a sufficient supply to the fetus (99). They also secrete proangiogenic factors such as members of the VEGF family (100).

In a murine model, different teams demonstrated an inhibitory effect of hCG on bone-marrow-derived dendritic cells (DCs) as well as on peripheral and local (decidual) DCs, therefore supporting the idea that hCG supports a tolerogenic rather than an immunogenic DC phenotype. Furthermore, hCG influence the differentiation and function of DCs, decreasing their ability to stimulate T-cell proliferation $(93,101,102)$.

hCG acts on other immune cells, like monocytes, by promoting their function and secretion of IL-8 (103) and also induces the functions of macrophages (104). By stimulating the function of macrophages, hCG cleans the endometrium by purifying apoptotic cells and fighting possible infections, which are two important mechanisms in the maintenance of pregnancy.

It has been shown that hCG could increase the ability of trophoblast cells to invade the extracellular matrix in vitro, which is accompanied by an increase in the expression of matrix metalloproteinase (MMP)-2, MMP-9, and VEGF and a decrease in the expression of tissue inhibitor matrix metalloproteinase (TIMP)-1 and TIMP-2. Peripheral blood mononuclear cells (PBMCs) support in vitro embryo invasion, and hCG enhances the effects of PBMCs (105).

An in vitro study supports the hypothesis that hCG is not a regulator of cell damage from peripheral blood dendritic cells (PBDCs). Nevertheless, in an inflammatory context, hCG seems to maintain the delicate balance between plasmoid dendritic cells and myeloid dendritic cells (MDCs) and seems to retain a tolerogenic MDC1profile, which might contribute to maintaining tolerance (106).

The administration of hCG could have an impact on the cytokine profile expressed by the endometrium (107). hCG directly or indirectly influences the genetic expression of several cytokines in cell signaling, proliferation, apoptosis, immunological modulation, tissue remodeling, and angiogenesis in endometrial stromal cells (108). A study was performed in a $3 \mathrm{D}$ cell culture model to demonstrate that hCG administration significantly alters the secretion of several cytokines in epithelial cells, stromal cells, and both cell types together (109). hCG inhibits the expression of tumor necrosis factor alpha (TNF $\alpha)$ and interferon gamma (IFN- $\gamma$ ) in the maternal/fetal interface and decreases the rate of resorption in abortive mouse models (110). Bai et al. cultured in vitro PBMCs with different concentrations of hCG and showed that hCG significantly inhibited IL- 6 and TNF $\alpha$ messenger RNA (mRNA) expression, indicating that hCG could inhibit the production of proinflammatory cytokines (111).

Control of complement system's activation in the fetomaternal environment seems critical for embryo development. One study has shown that hCG plays a role in this complement control, particularly on decay accelerating factor (DAF) and C3 protein, in in vitro and in vivo models (112).

Therefore, the hCG has an important immunomodulatory function, and its effects on the cells uNK and Treg (two major cell populations in the maintenance of pregnancy) demonstrate the crucial role of this embryonic signal as an immune regulator in the course of pregnancy. For more information on the regulation of these immune cells by hCG, you can read the article of Schumacher and Zenclussen (113).

\section{hCG AND AUTOIMMUNE DISEASES}

Pregnancy, which encourages a Th2-like environment, should encourage the production of antibodies making this type of disease more aggressive while improving Th1/Th17-related diseases.

Indeed, pregnancy is associated with an improvement in autoimmune disease symptoms associated with a Th1 profile $(114,115)$. The administration of hCG prevents (or decreases the severity) $\mathrm{T}$-cell mediated autoimmune diseases in mice and humans $(86,116-118)$.

Unfortunately, the effect of pregnancy is rather deleterious for diseases with a Th2 cytokine profile. Pregnancy is believed to constitute a Th2 environment, where heightened hormonal levels may influence disease and promote its effects $(119,120)$. Systemic lupus erythematosus (SLE) is thought to be a disease induced by autoantibodies. Pregnancy-associated flares have been reported in certain studies (114). Estrogens and prolactin have deleterious effects on SLE $(121,122)$, where progesterone and testosterone have beneficial effects $(122,123)$. SLE is characterized by broadspectrum antibody responses against autoantigens (124, 125). Higher levels of hCG have been reported in pregnant women with lupus (126), and nonpregnant patients with lupus also have high levels of hCG in their blood (127). A clinical case has been reported to show the appearance of SLE in three patients receiving hCG to induce ovulation (128). These results suggest that selective transductive, proliferative, and differentiative effects of hCG on adaptive immune cells may drive autoreactive responses in lupus environment and may also potentially provide insights into the association between the presence of higher hCG levels (or the administration of hCG) with the presence (or appearance) of humoral autoimmunity (129).

Regulatory B cells can modulate the immune response by creating an immunotolerant environment in autoimmune diseases and infections $(130,131)$. Several studies have suggested that B10 cells and Breg IL-35+ cells may play a role in autoimmune diseases and during pregnancy $(132,133)$. The combination of hCG and IL-35 induces the amplification of Breg IL-35+ and B10 cells that play a vital role in peripheral regulation during pregnancy (134). This phenomenon could have an influence on autoimmunity during pregnancy. hCG has also 
been identified as an important factor regulating phenotypes and the production of B-cell antibodies $(135,136)$. B1a B cells produce autoantibodies and proliferate in response to hCG (137).

Injections of hCG in patients are associated with ovarian hyperstimulation syndromes (OHSSs). (138, 139), a condition that is characterized by thrombosis that itself is related to the presence of antiphospholipid antibodies. In addition, increased levels of hCG have been associated with preeclampsia $(74,140)$, another thrombotic disease with possible autoimmune origins (141, 142). A study in a pregnant mouse model with lupus shows that hCG increases autoimmune responses in vitro and in vivo, events that are correlated with high responses at the cytokine level. In this study, hCG had a stimulating effect on the expression of CD40 and CD86 on B cells (129). On the contrary, after repeated hCG injections in nonobese diabetic mice, an induction of indoleamine 2,3-dioxygenase in dendritic cells could be observed. It resulted in an inhibition of autoreactive $\mathrm{T}$ cells and the prevention of diabetes onset (143). hCG can have effects that accumulate or decrease diseases of the immune system. These effects could become visible in a Th2 environment like pregnancy.

\section{AUTOIMMUNITY TO hCG?}

Cases of anti-hCG autoimmunity have been described, where patients have a history of repeated attempts to perform unsuccessful IVF treatments (144). The beta subunit of hCG is not immunogenic in women (145). Currently, the hCG vaccine is the only vaccine against pregnancy that has passed Phase II clinical trials. The Talwar et al. study provides evidence that persistent anti-hCG antibodies prevent pregnancy; in 1,224 sexually active women, only 1 pregnancy was observed. The authors also reported that fertility was restored when anti-hCG levels in the serum dropped below $35 \mathrm{ng} / \mathrm{ml}$ and thus that the effects of the vaccine were reversible (146). Contraception is achieved without impacting ovulation or menstrual disturbance.

Anti-hCG antibodies have been observed in young men who have been treated with exogenous hCG. The possible role of these particular antibodies in establishing and maintaining infertility is unclear. Hearn et al. reported that marmoset embryos exposed to anti-hCG immunoglobulins did not implant (147). Immunization against hCG has been shown to block fertility in baboons and rhesus monkeys (148). Anti-hCG vaccination studies in women provide evidence that a high level of antibodies may be a cause of fertility failure (149). Nevertheless, it is clear that not all women will develop autoimmunity to hCG after pregnancy or assisted reproductive treatment. In this context, a structural alteration, due to a mutation in one of the betahCG genes and/or a functional abnormality of the immune system, could be implicated. In one case of infertility described with hCG immunization, pregnancy was achieved as a result of plasmapheresis treatment to detoxify the patient's body (144). Immunotherapy could be beneficial for patients who suffered from repeated implantation failures (RIFs) previously. The problem would be the assessment of autoimmunity to hCG.

\section{INFUSION OF hCG DURING EMBRYO TRANSFER}

RIF is a source of great frustration for patients. They concern patients who have carried out several IVF treatments with embryo transfers that have failed in pregnancy. The RIFs have a variable definition, but the most generally used definitions correspond to transfers of three or more embryos or 10 or more embryos of good quality in a patient and no pregnancy was obtain. The causes of RIF include many factors of maternal or fetal origin (150). Unfortunately, in many patients, the origins of RIF are not identified. A team administered intracerebral PBMCs previously activated by hCG, and the percentage of pregnancy was better when these activated PBMC cells were administered in patients with RIF $(151,152)$.

Intrauterine hCG infusion has been proposed to improve the success rates of embryo transfer during IVF treatments. hCG plays an important role in synchronizing fetal and endometrial developments. Many studies in recent years have investigated the impact of this intrauterine hCG administration before embryo transfer in patients with repeated implantation failures. The results of these studies are controversial (153-155). The differences in design and population can explain the contradictory results. Endometrial receptivity may also affect the effectiveness of hCG administration. Further evidence from multicenter, randomized controlled trials are needed to confirm the potential therapeutical intervention of hCG. Several metaanalyses seem to show a positive effect in $\operatorname{RIF}$ patients $(156,157)$.

Since embryos can be transferred at the end of the cleavage stage or at the blastocyst stage, the clinical effect of hCG administration in the uterus may be different even if performed just before the embryo transfer. The influence of this administration on the pregnancy rate was controversial when it took place before the transfer of cleaved embryos (158-162), while there was no improvement in the rate when administration was performed before embryo transfer at the blastocyst stage $(154,163)$.

Following these clinical studies, various authors have studied the impact that this administration of hCG could have on the physiological level (Figure 2). One team showed that the percentage of peripheral Treg was increased compared to control patients when intrauterine hCG was administered (164). hCG was administered in the uterus from oocyte donors 3 days after their puncture to observe changes in the endometrium before embryo implantation. Infusion of hCG has been associated with endometrial synchronicity and reprogramming of stromal cell development following ovarian stimulation. Steroid receptors, estrogen receptor I (ESR I) and progesterone receptor (PGR), were significantly higher in treated vs. control patients (165).

Infusion of hCG during the implant window in a nonhuman primate model increased the expression of glycodelin by endometrial cells (166). Glycodelin is a protein secreted by the glandular portion of the endometrium that is expressed during and after the implant window (167). This protein has been suggested to play a role as an immunomodulator for the prevention of fetal allograft rejection by maternal cells $(168,169)$. 


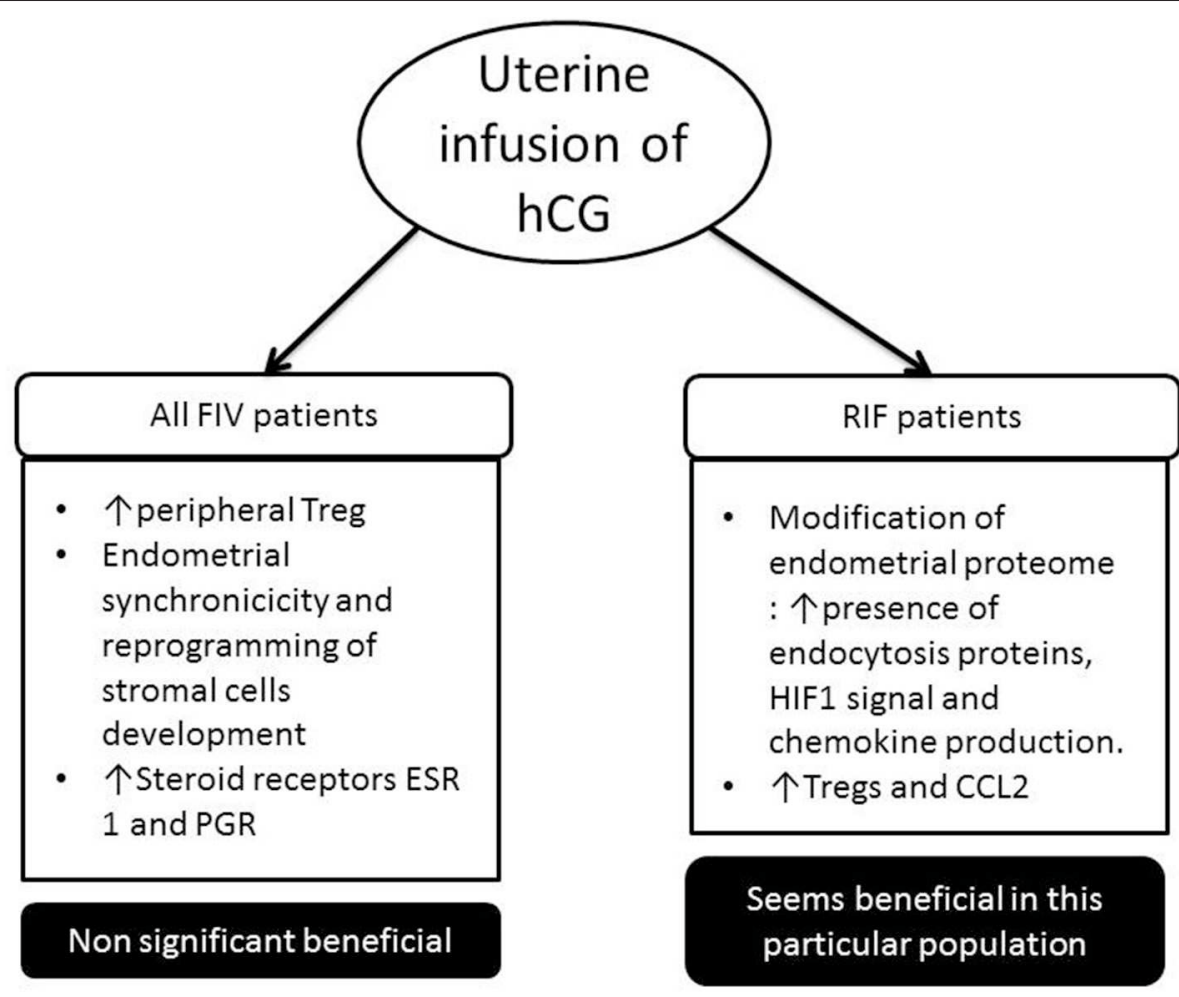

FIGURE 2 | Impact of uterine infusion of human chorionic gonadotrophin (hCG) in classical in vitro fertilization (IVF) patients and in patient suffering from repeated implantation failure (RIF) (at least three embryos have been transferred in these patients, and no pregnancy was observed). In classical IVF patients, in most studies, there has been no significant increase in pregnancy rate following the introduction of hCG intrauterine. Whereas in the RIF population, several studies show that it is beneficial for the implantation of the embryo.

One study showed for the first time that the endometrial proteome composition of RIF patients differs from fertile controls during the window of implantation. The in vivo infusion of hCG into the uterine cavity of RIF patients stimulated the presence of endocytosis proteins, hypoxia-inducible factor1 (HIF1) signal, and chemokine production (170). They hypothesize that the intrauterine infusion of hCG before an embryo transfer could improve the chemokine triggered embryoendometrial dialogue and intensify the angiogenesis and immune response. Another team showed that infusion of hCG increased the endometrial Tregs and CCL2 expression in RIF patients, while the Tregs migration was blocked with CCL2 small interfering RNA (siRNA) or CCR2 antagonist treatment in vitro (171). We believe that intrauterine infusion of hCG might be a new therapy for Treg-decreased RIF patients, which need to be explored in a larger prospective study.

\section{hCG AND MISCARRIAGES}

hCG and progesterone were analyzed concomitantly to determine whether their levels would be able to rapidly predict whether or not doubtful early pregnancy will continue, and the results provided a 48 -h diagnosis of viability in $41.1 \%$ of patients (172). Another study shows that hCG and progesterone levels 14 days after oocyte retrieval may be predictive for continued pregnancy in patients with recurrent miscarriages (173). Another team showed similar results with the analysis of hCG 11 days after embryo transfer (28). hCG-H could also be used as a predictor for progressive pregnancy vs. nonprogressive pregnancy (174).

Recurrent spontaneous abortion (RSA) is one of the most common complications of early pregnancy. This affects about $10-20 \%$ of all pregnancies (175). In $80 \%$ of cases, spontaneous miscarriages occur during the first 12 weeks of pregnancy. The causes of embryo loss are variable and include cytogenetic abnormalities, maternal problems (e.g., lupus erythematosus or diabetes), uterine malformations, cigarette smoking, or inadequate placental development $(176,177)$. One study showed that hCG-related cytokines, macrophage inflammatory protein 1 alpha (MIP1a)/hCG, granulocyte-colony stimulating factor (GCSF)/IL-1ra, and MIP1a/TGF-beta1 ratios after 4 weeks of pregnancy were significantly altered in women with spontaneous miscarriages (178). hCG treatment in a mouse model of spontaneous miscarriages increases the number of Treg cells at the maternal/fetal interface and decreases the number of miscarriages. Schumacher et al. suggest that levels of hCG and Treg in the decidual and placenta of pregnant women with RSA are lower than in normal pregnant women (90). 
A meta-analysis of five studies was conducted to determine whether hCG treatments could prevent miscarriage in patients. The results of this study show that there is a nonsignificant beneficial trend for women with RSA to receive hCG in early pregnancy. However, this result remains ambiguous and therefore does not demonstrate the interest of treating patients with hCG in the event of a history of miscarriages (176). The combination of hCG and immunoglobulin treatment on Th17+ cells and Foxp3+ Treg cells in patients with RSA was analyzed, and the Th17/Treg ratio was decreased, which could be beneficial for these patients (179). Another study investigated the impact of hCG in the regulation of FOXP3 + Treg cells in patients with RSA and may have a positive impact in these patients (155).

\section{CONCLUSIONS}

hCG is involved in many processes ensuring the smooth progress of a pregnancy: the recognition of the pregnancy by the maternal organism, the maintenance of the corpus luteum, the stimulation progesterone production, the strengthening of the implantation of the embryo, angiogenesis, and vasculogenesis necessary for placental development, control of trophoblast

\section{REFERENCES}

1. Strott CA, Yoshimi T, Ross GT, Lipsett MB. Ovarian physiology: relationship between plasma LH and steroidogenesis by the follicle and corpus luteum; effect of HCG. J Clin Endocrinol Metab. (1969) 29:115767. doi: 10.1210/jcem-29-9-1157

2. Policastro PF, Daniels-McQueen S, Carle G, Boime I. A map of the hCG beta-LH beta gene cluster. J Biol Chem. (1986) 261:5907-16.

3. Cole LA. New discoveries on the biology and detection of human chorionic gonadotropin. Reprod Biol Endocrinol. (2009) 7:8. doi: 10.1186/1477-7827-7-8

4. Gridelet V, Tsampalas M, Berndt S, Hagelstein MT, Charlet-Renard C, Conrath V, et al. Evidence for cross-talk between the LH receptor and LH during implantation in mice. Reprod Fertil Dev. (2013) 25:51122. doi: 10.1071/RD11241

5. Cole LA, Butler SA. Hyperglycosylated human chorionic gonadotropin and human chorionic gonadotropin free $\beta$-subunit: tumor markers and tumor promoters. J Reprod Med. (2008) 53:499-512.

6. Guibourdenche J, Handschuh K, Tsatsaris V, Gerbaud P, Leguy MC, Muller F, et al. Hyperglycosylated hCG is a marker of early human trophoblast invasion. J Clin Endocrinol Metab. (2010) 95:E240-4. doi: 10.1210/jc.2010-0138

7. Hamada AL, Nakabayashi K, Sato A, Kiyoshi K, Takamatsu Y, LaoagFernandez JB, et al. Transfection of antisense chorionic gonadotropin $\beta$ gene into choriocarcinoma cells suppresses the cell proliferation and induces apoptosis. J Clin Endocrinol Metab. (2005) 90:48739. doi: 10.1210/jc.2004-2458

8. Sasaki Y, Ladner DG, Cole LA. Hyperglycosylated human chorionic gonadotropin and the source of pregnancy failures. Fertil Steril. (2008) 89:1781-6. doi: 10.1016/j.fertnstert.2007.03.010

9. Cole LA. Hyperglycosylated hCG. Placenta. (2007) 28:97786. doi: 10.1016/j.placenta.2007.01.011

10. Cole LA, Dai D, Butler SA, Leslie KK, Kohorn EI. Gestational trophoblastic diseases: 1. Pathophysiology of hyperglycosylated hCG. Gynecol Oncol. (2006) 102:145-50. doi: 10.1016/j.ygyno.2005.12.047

11. Koistinen H, Koel M, Peters M, Rinken A, Lundin K, Tapanainen JS, et al. Hyperglycosylated hCG activates LH/hCG-receptor with lower activity than hCG. Mol Cell Endocrinol. (2018) 479:103-9. doi: 10.1016/j.mce.2018.09.006 differentiation, and finally immune regulation in the maternal/ fetal interface.

These different actions have allowed this hormone to be considered as a treatment in cases of RIF and RSA. The future will tell if hCG is an effective tool to help these patients to improve their uterine receptivity. We believe that patient populations need to be more targeted to study hCG to have a beneficial effect from this hormone. Targeting must focus on the immunological and angiogenic profile of the patients to detect their specific problems.

\section{AUTHOR CONTRIBUTIONS}

VGr has written the article with the help of SP. VGe, BP, $\mathrm{MN}$, and J-MF have corrected the article and made remarks and suggestions.

\section{ACKNOWLEDGMENTS}

VGr has a Ph.D. in biomedical sciences. She works as a scientist in an ART center. VGe is Research Director of F.S.R.-NFSR of Belgium. These studies are supported by the University of Liège.

12. Evans J, Salamonsen LA, Menkhorst E, Dimitriadis E. Dynamic changes in hyperglycosylated human chorionic gonadotrophin throughout the first trimester of pregnancy and its role in early placentation. Hum Reprod. (2015) 30:1029-38. doi: 10.1093/humrep/dev016

13. Berndt S, Blacher S, Munaut C, Detilleux J, Perrier d'Hauterive S, Huhtaniemi I, et al. Hyperglycosylated human chorionic gonadotropin stimulates angiogenesis through TGF- $\beta$ receptor activation. FASEB J. (2013) 27:1309-21. doi: 10.1096/fj.12-213686

14. Kovalevskaya G, Kakuma T, Schlatterer J, O'Connor JF. Hyperglycosylated HCG expression in pregnancy: cellular origin and clinical applications. $\mathrm{Mol}$ Cell Endocrinol. (2007) 260-262:237-43. doi: 10.1016/j.mce.2006.02.021

15. Bersinger NA, Wunder DM, Nicolas M, Birkhauser MH, Porquet D, Guibourdenche J. Serum hyperglycosylated human chorionic gonadotropin to predict the gestational outcome in in vitro fertilization/intracytoplasmic sperm injection pregnancies. Fetal Diagn Ther. (2008) 24:74-8. doi: 10.1159/000132412

16. Butler SA, Ikram MS, Mathieu S, Iles RK. The increase in bladder carcinoma cell population induced by the free beta subunit of human chorionic gonadotrophin is a result of an anti-apoptosis effect and not cell proliferation. Br J Cancer. (2000) 82:1553-6. doi: 10.1054/bjoc.2000.1177

17. Cole LA, Butler S. Hyperglycosylated hCG, hCGbeta and Hyperglycosylated hCGbeta: interchangeable cancer promoters. Mol Cell Endocrinol. (2012) 349:232-8. doi: 10.1016/j.mce.2011.10.029

18. Cole LA, Gutierrez JM. Production of human chorionic gonadotropin during the normal menstrual cycle. J Reprod Med. (2009) 54:245-50.

19. Cole LA. "Background" human chorionic gonadotropin in healthy, nonpregnant women. Clin Chem. (2005) 51:17656. doi: 10.1373/clinchem.2005.056507

20. Cole LA, Laidler LL, Muller CY. USA hCG reference service, 10-year report. Clin Biochem. (2010) 43:1013-22. doi: 10.1016/j.clinbiochem.2010.05.006

21. Birken S, Maydelman Y, Gawinowicz MA, Pound A, Liu Y, Hartree AS. Isolation and characterization of human pituitary chorionic gonadotropin. Endocrinology. (1996) 137:1402-11. doi: 10.1210/endo.137.4.86 25917

22. Jurisicova A, Antenos M, Kapasi K, Meriano J, Casper RF. Variability in the expression of trophectodermal markers beta-human chorionic gonadotrophin, human leukocyte antigen-G and pregnancy specific beta-1 glycoprotein by the human blastocyst. Hum Reprod. (1999) 14:1852-8. 
23. Bonduelle ML, Dodd R, Liebaers I, Van Steirteghem A, Williamson R, Akhurst R. Chorionic gonadotrophin- $\beta$ mRNA, a trophoblast marker, is expressed in human 8-cell embryos derived from tripronucleate zygotes. Hum Reprod. (1988) 3:909-14.

24. Lopata A, Hay DL. The potential of early human embryos to form blastocysts, hatch from their zona and secrete HCG in culture. Hum Reprod. (1989) 4:87-94.

25. Hoshina M, Boothby M, Hussa R, Pattillo R, Camel HM, Boime I. Linkage of human chorionic gonadotrophin and placental lactogen biosynthesis to trophoblast differentiation and tumorigenesis. Placenta. (1985) 6:163-72.

26. Braunstein GD, Rasor J, Danzer H, Adler D, Wade ME. Serum human chorionic gonadotropin levels throughout normal pregnancy. Am J Obs Gynecol. (1976) 126:678-81.

27. Korevaar TIM, Steegers EAP, Rijke YB De, Jaddoe VWV, Tiemeier H, Visser TJ. Reference ranges and determinants of total hCG levels during pregnancy: the Generation R Study. Eur J Epidemiol. (2015) 30:105766. doi: 10.1007/s10654-015-0039-0

28. Xiong F, Li G, Sun Q, Chen P, Wang Z, Wan C, et al. Obstetric and perinatal outcomes of pregnancies according to initial maternal serum HCG concentrations after vitrified-warmed single blastocyst transfer. Reprod Biomed Online. (2019) 38:455-64. doi: 10.1016/j.rbmo.2018.12.040

29. Sonoda N, Katabuchi H, Tashiro H, Ohba T, Nishimura R, Minegishi $\mathrm{T}$, et al. Expression of variant luteinizing hormone/chorionic gonadotropin receptors and degradation of chorionic gonadotropin in human chorionic villous macrophages. Placenta. (2005) 26:298-307. doi: 10.1016/j.placenta.2004.07.001

30. Katabuchi H, Ohba T. Human chorionic villous macrophages as a fetal biological shield from maternal chorionic gonadotropin. Dev Growth Differ. (2008) 50:299-306. doi: 10.1111/j.1440-169X.2008.01030.x

31. Yamaguchi M, Ohba T, Tashiro H, Yamada G, Katabuchi H. Human chorionic gonadotropin induces human macrophages to form intracytoplasmic vacuoles mimicking Hofbauer cells in human chorionic villi. Cells Tissues Organs. (2013) 197:127-35. doi: 10.1159/000342806

32. Sirikunalai P, Wanapirak C, Sirichotiyakul S, Tongprasert F, Srisupundit $\mathrm{K}$, Luewan $\mathrm{S}$, et al. Associations between maternal serum free beta human chorionic gonadotropin ( $\beta$-hCG) levels and adverse pregnancy outcomes. $J$ Obstet Gynaecol. (2016) 36:178-82. doi: 10.3109/01443615.2015.1036400

33. Craig WY, Haddow JE, Palomaki GE, Roberson M. Major fetal abnormalities associated with positive screening tests for Smith-Lemli-Opitz syndrome (SLOS). Prenat Diagn. (2007) 27:409-14. doi: 10.1002/pd.1699

34. Norris W, Nevers T, Sharma S, Kalkunte S. Review: HCG, preeclampsia and regulatory $\mathrm{T}$ cells. Placenta. (2011) 32:S1825. doi: 10.1016/j.placenta.2011.01.009

35. Barjaktarovic M, Korevaar TIM, Jaddoe VWV, de Rijke YB, Peeters RP, Steegers EAP. Human chorionic gonadotropin and risk of pre-eclampsia: prospective population-based cohort study. Ultrasound Obstet Gynecol. (2019) 54:477-83 doi: 10.1002/uog.20256

36. Barjaktarovic M, Korevaar TIM, Jaddoe VWV, de Rijke YB, Visser TJ, Peeters $\mathrm{RP}$, et al. Human chorionic gonadotropin (hCG) concentrations during the late first trimester are associated with fetal growth in a fetal sex-specific manner. Eur J Epidemiol. (2017) 32:135-44. doi: 10.1007/s10654-016-0201-3

37. Stevens FT, Katzorke N, Tempfer C, Kreimer U, Bizjak GI, Fleisch MC, et al. Gestational trophoblastic Disorders: An update in 2015. Geburtshilfe Frauenheilkd. (2015) 75:1043-50. doi: 10.1055/s-0035-1558054

38. Wang Z, Gao Y, Zhang D, Li Y, Luo L, Xu Y. Predictive value of serum $\beta$ human chorionic gonadotropin for early pregnancy outcomes. Arch Gynecol Obstet. (2019) 265:7-10. doi: 10.1007/s00404-019-05388-2

39. Paulesu L, Rao C V., Ietta F, Pietropolli A, Ticconi C. HCG and its disruption by environmental contaminants during human pregnancy. Int J Mol Sci. (2018) 19:1-11. doi: 10.3390/ijms19030914

40. Ghorani E, Kaur B, Fisher R, Short D, Joneborg U, W CarlsonJ, et al. Correspondence Pembrolizumab is effective for drug- trophoblastic neoplasia. Lancet. (2017) 390:2343-5. doi: 10.1016/S0140-6736(17)32894-5

41. Singh P, Sarkar M, Agrawal U, Huhtaniemi I, Pal R. The transgenic expression of the $\beta$-subunit of human chorionic gonadotropin influences the growth of implanted tumor cells. Oncotarget. (2018) 9:3467080. doi: 10.18632 /oncotarget. 26158
42. Lenhard M, Tsvilina A, Schumacher L, Kupka M, Ditsch N, Mayr $\mathrm{D}$, et al. Human chorionic gonadotropin and its relation to grade, stage and patient survival in ovarian cancer. BMC Cancer. (2012) 12:2. doi: 10.1186/1471-2407-12-2

43. Moulton HM, Yoshihara PH, Mason DH, Iversen PL, Triozzi PL. Active specific immunotherapy with a $\beta$-human chorionic gonadotropin peptide vaccine in patients with metastatic colorectal cancer: Antibody response is associated with improved survival. Clin Cancer Res. (2002) 8:2044-51.

44. Sachdeva R, Bhardwaj N, Huhtaniemi I, Aggrawal U, Jain SK, Zaidi R, et al. Transgenesis-Mediated reproductive dysfunction and tumorigenesis: effects of immunological neutralization. PLoS ONE. (2012) 7:e51125. doi: 10.1371/journal.pone.0051125

45. Kvirkvelia N, Chikadze N, Makinde J, McBride JD, Porakishvili N, Hills $\mathrm{FA}$, et al. Investigation of factors influencing the immunogenicity of hCG as a potential cancer vaccine. Clin Exp Immunol. (2018) 193:7383. doi: $10.1111 /$ cei. 13131

46. Hirose T. Exogenous stimulation of corpus luteum formation in the rabbit: influence of extracts of human placenta, decidua, fetus, hydatid mole, and corpus luteum on the rabbit gonad. J Jpn Gynecol Soc. (1920) 16:1055.

47. Fang L, Yu Y, Li Y, Wang S, Zhang R, Guo Y, et al. Human chorionic gonadotropin-induced amphiregulin stimulates aromatase expression in human granulosa-lutein cells: a mechanism for estradiol production in the luteal phase. (2019) 34:2018-26. doi: 10.1093/humrep/dez171

48. Convissar S, Winston NJ, Fierro MA, Scoccia H, Zamah AM, Stocco C. Sp1 regulates steroidogenic genes and LHCGR expression in primary human luteinized granulosa cells. J Steroid Biochem Mol Biol. (2019) 190:18392. doi: 10.1016/j.jsbmb.2019.04.003

49. Ohlsson R, Larsson E, Nilsson O, Wahlstrom T, Sundstrom P. Blastocyst implantation precedes induction of insulin-like growth factor II gene expression in human trophoblasts. Development. (1989) 106:555-9.

50. Perrier d'Hauterive S, Charlet-Renard C, Berndt S, Dubois M, Munaut C, Goffin F, et al. Human chorionic gonadotropin and growth factors at the embryonic-endometrial interface control leukemia inhibitory factor (LIF) and interleukin 6 (IL-6) secretion by human endometrial epithelium. Hum Reprod. (2004) 19:2633-43. doi: 10.1093/humrep/deh450

51. Srisuparp S, Strakova Z, Fazleabas AT. The role of chorionic gonadotropin (CG) in blastocyst implantation. Arch Med Res. (2001) 32:627-34. doi: 10.1016/S0188-4409(01)00330-7

52. Lobo SC, Srisuparp S, Peng X, Fazleabas AT. Uterine receptivity in the baboon: modulation by chorionic gonadotropin. Semin Reprod Med. (2001) 19:69-74. doi: 10.1055/s-2001-13913

53. Shi QJ, Lei ZM, Rao C V, Lin J. Novel role of human chorionic gonadotropin in differentiation of human cytotrophoblasts. Endocrinology. (1993) 132:1387-95. doi: 10.1210/endo.132.3.7679981

54. North RA, Whitehead R, Larkins RG. Stimulation by human chorionic gonadotropin of prostaglandin synthesis by early human placental tissue. $J$ Clin Endocrinol Metab. (1991) 73:60-70. doi: 10.1210/jcem-73-1-60

55. Weedon-Fekjaer MS, Tasken K, Weedon-Fekjær MS, Taskén K. Review: spatiotemporal dynamics of hCG/cAMP signaling and regulation of placental function. Placenta. (2012) 33(Suppl.):S8791. doi: 10.1016/j.placenta.2011.11.003

56. Lee CL, Chiu PC, Hautala L, Salo T, Yeung WS, Stenman UH, et al. Human chorionic gonadotropin and its free $\beta$-subunit stimulate trophoblast invasion independent of LH/hCG receptor. Mol Cell Endocrinol. (2013) 375:43-52. doi: 10.1016/j.mce.2013.05.009

57. Nwabuobi C, Arlier S, Schatz F, Guzeloglu-Kayisli O, Lockwood CJ, Kayisli UA. hCG: Biological functions and clinical applications. Int J Mol Sci. (2017) 18:1-15. doi: 10.3390/ijms18102037

58. Tsampalas M, Gridelet V, Berndt S, Foidart JM, Geenen V, d'Hauterive SP. Human chorionic gonadotropin: A hormone with immunological and angiogenic properties. J Reprod Immunol. (2010) 85:93-8. doi: 10.1016/j.jri.2009.11.008

59. Polese B, Gridelet V, Araklioti E, Martens H, d'Hauterive SP, Geenen V. The endocrine milieu and CD4 T-lymphocyte polarization during pregnancy. Front Endocrinol. (2014) 5:106. doi: 10.3389/fendo.2014.00106

60. Berndt S, Perrier d'Hauterive S, Blacher S, Pequeux C, Lorquet S, Munaut $\mathrm{C}$, et al. Angiogenic activity of human chorionic gonadotropin through LH 
receptor activation on endothelial and epithelial cells of the endometrium. FASEB J. (2006) 20:2630-2. doi: 10.1096/fj.06-5885fje

61. Berndt S, Blacher S, Perrier d'Hauterive S, Thiry M, Tsampalas M, Cruz A, et al. Chorionic gonadotropin stimulation of angiogenesis and pericyte recruitment. J Clin Endocrinol Metab. (2009) 94:456774. doi: 10.1210/jc.2009-0443

62. Herr F, Baal N, Reisinger K, Lorenz A, McKinnon T, Preissner KT, et al. HCG in the regulation of placental angiogenesis. Results of an in vitro study. Placenta. (2007) 28 (Suppl. A):S85-93. doi: 10.1016/j.placenta.2007. 02.002

63. Bourdiec A, Bedard D, Rao C V, Akoum A. Human chorionic gonadotropin regulates endothelial cell responsiveness to interleukin 1 and amplifies the cytokine-mediated effect on cell proliferation, migration and the release of angiogenic factors. Am J Reprod Immunol. (2013) 70:12738. doi: 10.1111/aji.12080

64. Reisinger K, Baal N, McKinnon T, Munstedt K, Zygmunt M. The gonadotropins: tissue-specific angiogenic factors? Mol Cell Endocrinol. (2007) 269:65-80. doi: 10.1016/j.mce.2006.11.015

65. Zhang Z, Huang Y, Zhang J, Liu Z, Lin Q, Wang Z. Activation of NF-кB signaling pathway during HCG-induced VEGF expression in luteal cells. Cell Biol Int. (2019) 43:344-9. doi: 10.1002/cbin.11090

66. Surico D, Farruggio S, Marotta P, Raina G, Mary D, Surico N, et al. Human chorionic gonadotropin protects vascular endothelial cells from oxidative stress by apoptosis inhibition, cell survival signalling activation and mitochondrial function protection. Cell Physiol Biochem. (2015) 36:210820. doi: 10.1159/000430178

67. Fournier T, Guibourdenche J, Evain-brion D. Review : hCGs : different sources of production, different glycoforms and functions. Placenta. (2015) 36:S60-S65. doi: 10.1016/j.placenta.2015.02.002

68. Iles RK, Delves PJ, Butler SA. Molecular and Cellular Endocrinology Does hCG or hCG $L_{L}^{N}$ play a role in cancer cell biology? Mol Cell Endocrinol. (2010) 329:62-70. doi: 10.1016/j.mce.2010.07.014

69. Lapthorn AJ1, Harris DC, Littlejohn A, Lustbader JW, Canfield RE, Machin KJ, et al. Crystal structure of human chorionic gonadotropin. Nature. (1994) 369:455-61. doi: 10.1038/369455a0

70. Lehnert SA AR. Embryonic expression pattern of TGF beta type-1 RNA suggests both paracrine and autocrine mechanisms of action. Development. (1988) 104:263-73.

71. Mitri F, Bentov Y, Behan LA, Esfandiari N, Casper RF. GONADAL PHYSIOLOGY AND DISEASE A novel compound heterozygous mutation of the luteinizing hormone receptor -implications for fertility. Am J Hum Genet. (2014) 31:787-94. doi: 10.1007/s10815-014-0249-5

72. Gallardo V, González M, Toledo F, Sobrevia L. Role of heme oxygenase 1 and human chorionic gonadotropin in pregnancy associated diseases. Elsevier B.V. (2019) 1866:165522. doi: 10.1016/j.bbadis.2019.07.016

73. Jahanshahi M, Saeidi M, Nikmahzar E, Babakordi F, Bahlakeh G. Effects of hCG on reduced numbers of hCG receptors in the prefrontal cortex and cerebellum of rat models of Alzheimer's disease. Biotech Histochem. (2019) 94:360-5. doi: 10.1080/10520295.2019.1571228

74. El-Baradie SMY, Mahmoud M, Makhlouf HH. Elevated serum levels of Interleukin-15, interleukin-16, and human chorionic gonadotropin in women with preeclampsia. J Obstet Gynaecol Canada. (2009) 31:1428. doi: 10.1016/S1701-2163(16)34098-1

75. Nikmahzar E, Jahanshahi M, Elyasi L, Saeidi M, Babakordi F, Bahlakeh G. Human chorionic gonadotropin attenuates amyloid- $\beta$ plaques induced by streptozotocin in the rat brain by affecting cytochrome c-ir neuron density. Iran J Basic Med Sci. (2019) 22:166-72. doi: 10.22038/ijbms.2018.31412.7569

76. Raghupathy R. Th1-type immunity is incompatible with successful pregnancy. Immunol Today. (1997) 18:47882. doi: 10.1016/S0167-5699(97)01127-4

77. Raghupathy R, Makhseed M, Azizieh F, Hassan N, Al-Azemi M, Al-Shamali E. Maternal Th1- and Th2-type reactivity to placental antigens in normal human pregnancy and unexplained recurrent spontaneous abortions. Cell Immunol. (1999) 196:122-30. doi: 10.1006/cimm.1999.1532

78. Wang W-J, Hao C-F, Yi-Lin, Yin G-J, Bao S-H, Qiu L-H, et al. Increased prevalence of T helper 17 (Th17) cells in peripheral blood and decidua in unexplained recurrent spontaneous abortion patients. J Reprod Immunol. (2010) 84:164-70. doi: 10.1016/j.jri.2009.12.003
79. Sereshki N, Gharagozloo M, Ostadi V, Ghahiri A, Roghaei MA, Mehrabian $\mathrm{F}$, et al. Variations in T-helper 17 and regulatory T cells during the menstrual cycle in peripheral blood of women with recurrent spontaneous abortion. Int J Fertil Steril. (2014) 8:59-66.

80. Ricketts RM, Jones DB. Differential effect of human chorionic gonadotrophin on lymphocyte proliferation induced by mitogens. $J$ Reprod Immunol. (1985) 7:225-32. doi: 10.1016/0165-0378(85)90053-1

81. Yagel S, Parhar RS, Lala PK. Trophic effects of first-trimester human trophoblasts and human chorionic gonadotropin on lymphocyte proliferation. Am J Obstet Gynecol. (1989) 160:94653. doi: 10.1016/0002-9378(89)90315-3

82. Prast J, Saleh L, Husslein H, Sonderegger S, Helmer H, Knöfler M. Human chorionic gonadotropin stimulates trophoblast invasion through extracellularly regulated kinase and AKT signaling. Endocrinology. (2008) 149:979-87. doi: 10.1210/en.2007-1282

83. Palaniappan M, Menon KMJ. Human chorionic gonadotropin stimulates theca-interstitial cell proliferation and cell cycle regulatory proteins by a cAMP-dependent activation of AKT/mTORC1 signaling pathway. Mol Endocrinol. (2010) 24:1782-93. doi: 10.1210/me.2010-0044

84. Ge YC, Li JN, Ni XT, Guo CM, Wang WS, Duan T, et al. Cross talk between cAMP and p38 MAPK pathways in the induction of leptin by hCG in human placental syncytiotrophoblasts. Reproduction. (2011) 142:36975. doi: 10.1530/REP-11-0053

85. Adcock 3rd EW, Teasdale T, August CS, Cox S, Meschia G, Ballaglia TC, et al. Human chorionic gonadotropin: its possible role in maternal lymphocyte suppression. Science. (1973) 181:845-7. doi: 10.1126/science.181.4102.845

86. Khil LY, Jun HS, Kwon H, Yoo JK, Kim S, Notkins AL, et al. Human chorionic gonadotropin is an immune modulator and can prevent autoimmune diabetes in NOD mice. Diabetologia. (2007) 50:214755. doi: 10.1007/s00125-007-0769-y

87. Schumacher A, Brachwitz N, Sohr S, Engeland K, Langwisch S, Dolaptchieva $\mathrm{M}$, et al. Human chorionic gonadotropin attracts regulatory $\mathrm{T}$ cells into the fetal-maternal interface during early human pregnancy. J Immunol. (2009) 182:5488-97. doi: 10.4049/jimmunol.0803177

88. Lea RG, Sandra O. Immunoendocrine aspects of endometrial function and implantation. Reproduction. (2007) 134:389-404. doi: 10.1530/REP-07-0167

89. Fujiwara H. Do circulating blood cells contribute to maternal tissue remodeling and embryo-maternal cross-talk around the implantation period? Mol Hum Reprod. (2009) 15:335-43. doi: 10.1093/molehr/gap027

90. Schumacher A, Heinze K, Witte J, Poloski E, Linzke N, Woidacki K, et al. Human chorionic gonadotropin as a central regulator of pregnancy immune tolerance. J Immunol. (2013) 190:2650-8. doi: 10.4049/jimmunol.1202698

91. Furcron A-E, Romero R, Mial TN, Balancio A, Panaitescu B, Hassan SS, et al. Human chorionic gonadotropin Has Anti-Inflammatory effects at the Maternal-Fetal interface and prevents Endotoxin-Induced preterm birth, but causes dystocia and fetal compromise in micel. Biol Reprod. (2016) 94:25-8. doi: 10.1095/biolreprod.116.139345

92. Zamorina SA, Litvinova LS, Yurova KA, Khaziakhmatova OG, Timganova VP, Bochkova MS, et al. The role of human chorionic gonadotropin in regulation of naïve and memory $\mathrm{T}$ cells activity in vitro. Int Immunopharmacol. (2018) 54:33-8. doi: 10.1016/j.intimp.2017.10.029

93. Schumacher A. Human chorionic gonadotropin as a pivotal endocrine immune regulator initiating and preserving fetal tolerance. Int J Mol Sci. (2017) 18:E2166. doi: 10.3390/ijms18102166

94. Lash GE, Robson SC, Bulmer JN. Review: functional role of uterine natural killer (uNK) cells in human early pregnancy decidua. Placenta. (2010) 31 (Suppl.):S87-92. doi: 10.1016/j.placenta.2009.12.022

95. Yagel S. The developmental role of natural killer cells at the fetal-maternal interface. Am J Obs Gynecol. (2009) 201:34450. doi: 10.1016/j.ajog.2009.02.030

96. Moffett A, Colucci F. Uterine NK cells: active regulators at the maternal-fetal interface. J Clin Invest. (2014) 124:1872-9. doi: 10.1172/JCI68107

97. Bansal AS, Bora SA, Saso S, Smith JR, Johnson MR, Thum MY. Mechanism of human chorionic gonadotrophin-mediated immunomodulation in pregnancy. Expert Rev Clin Immunol. (2012) 8:747-53. doi: 10.1586/ eci. 12.77

98. Kane N, Kelly R, Saunders PTK, Critchley HOD. Proliferation of uterine natural killer cells is induced by human chorionic gonadotropin and 
mediated via the mannose receptor. Endocrinology. (2009) 150:28828. doi: 10.1210/en.2008-1309

99. Ashkar AA, Croy BA. Functions of uterine natural killer cells are mediated by interferon gamma production during murine pregnancy. Semin Immunol. (2001) 13:235-41. doi: 10.1006/smim.2000.0319

100. Hanna J, Goldman-Wohl D, Hamani Y, Avraham I, Greenfield C, Natanson-Yaron S, et al. Decidual NK cells regulate key developmental processes at the human fetal-maternal interface. Nat Med. (2006) 12:106574. doi: $10.1038 / \mathrm{nm} 1452$

101. Wan H, Versnel MA, Leijten LM, van Helden-Meeuwsen CG, Fekkes $\mathrm{D}$, Leenen PJ, et al. Chorionic gonadotropin induces dendritic cells to express a tolerogenic phenotype. J Leukoc Biol. (2008) 83:894901. doi: 10.1189/jlb.0407258

102. Dauven D, Ehrentraut S, Langwisch S, Zenclussen AC, Schumacher A. Immune modulatory effects of human chorionic gonadotropin on dendritic cells supporting fetal survival in murine pregnancy. Front Endocrinol. (2016) 7:146. doi: $10.3389 /$ fendo. 2016.00146

103. Kosaka K, Fujiwara H, Tatsumi K, Yoshioka S, Sato Y, Egawa H, et al. Human chorionic gonadotropin (HCG) activates monocytes to produce interleukin8 via a different pathway from luteinizing hormone/HCG receptor system. J Clin Endocrinol Metab. (2002) 87:5199-208. doi: 10.1210/jc.2002-020341

104. Wan H, Versnel MA, Cheung WY, Leenen PJ, Khan NA, Benner $\mathrm{R}$, et al. Chorionic gonadotropin can enhance innate immunity by stimulating macrophage function. J Leukoc Biol. (2007) 82:926-33. doi: $10.1189 / \mathrm{jlb} .0207092$

105. Nakayama T. Human peripheral blood mononuclear cells (PBMC) in early pregnancy promote embryo invasion in vitro: HCG enhances the effects of PBMC. Hum Reprod. (2002) 17:207-212. doi: 10.1093/humrep/17.1.207

106. Sauss K, Ehrentraut S, Zenclussen AC, Schumacher A. The pregnancy hormone human chorionic gonadotropin differentially regulates plasmacytoid and myeloid blood dendritic cell subsets. Am J Reprod Immunol. (2018) 79:e12837. doi: 10.1111/aji.12837

107. Licht P, von Wolff M, Berkholz A, Wildt L. Evidence for cycle-dependent expression of full-length human chorionic gonadotropin/luteinizing hormone receptor mRNA in human endometrium and decidua. Fertil Steril. (2003) 79(Suppl. 1):718-23. doi: 10.1016/S0015-0282(02)04822-7

108. Bourdiec A, Calvo E, Rao CV, Akoum A. Transcriptome analysis reveals new insights into the modulation of endometrial stromal cell receptive phenotype by embryo-derived signals interleukin-1 and human chorionic gonadotropin: possible involvement in early embryo implantation. PLoS ONE. (2013) 8:e64829. doi: 10.1371/journal.pone.0064829

109. Srivastava A, Sengupta J, Kriplani A, Roy KK, Ghosh D. Profiles of cytokines secreted by isolated human endometrial cells under the influence of chorionic gonadotropin during the window of embryo implantation. Reprod Biol Endocrinol. (2013) 11:116. doi: 10.1186/1477-7827-11-116

110. Wang H, Liu F, Liu X, XW Z. The effect of hCG bind immunoglobulin G on maternal-interface's Th1/Th2 type cytokines and pregnancy's outcome of abortion model. Chinese J Birth Heal Hered. (2013) 21:53-5.

111. Bai H, Pan J, Jia X, Huang H. The inhibition effect of human chorionic gonadotropin (hCG) on mRNA expression of cytokines initiated inflammatory reaction. Chinese J Immunol. (2003) 19:193-203.

112. Palomino WA, Argandoña F, Azúa R, Kohen $\mathrm{P}$, Devoto L. Complement $\mathrm{C} 3$ and decay-accelerating factor expression levels are modulated by human chorionic gonadotropin in endometrial compartments during the implantation window. Reprod Sci. (2013) 20:1103-10. doi: 10.1177/1933719113477486

113. Schumacher A, Zenclussen AC. Human chorionic gonadotropin-mediated immune responses that facilitate embryo implantation and placentation. Front Immunol. (2019) 10:2896. doi: 10.3389/fimmu.2019.02896

114. Borchers AT, Naguwa SM, Keen CL, Gershwin ME. The implications of autoimmunity and pregnancy. J Autoimmun. (2010) 34:J287-99. doi: 10.1016/j.jaut.2009.11.015

115. Buyon JP. The effects of pregnancy on autoimmune diseases. J Leukoc Biol. (1998) 63:281-7. doi: 10.1002/jlb.63.3.281

116. Song XY, Zeng L, Jin W, Pilo CM, Frank ME, Wahl SM. Suppression of streptococcal cell wall-induced arthritis by human chorionic gonadotropin. Arthritis Rheum. (2000) 43:206472. doi: 10.1002/1529-0131(200009)43:9<2064::AID-ANR18>3.0.CO;2-Z
117. Van Broekhoven F, De Graaf MT, Bromberg JE, Hooijkaas H, Van Den Bent MJ, De Beukelaar JW, et al. Human chorionic gonadotropin treatment of anti-Hu-associated paraneoplastic neurological syndromes. J Neurol Neurosurg Psychiatry. (2010) 81:1341-4. doi: 10.1136/jnnp.2009. 177865

118. Li N, Shigihara T, Tzioufas AG, Notkins AL, Yoon JW, Jun HS. Human chorionic gonadotropin prevents Sjögren's syndrome-like exocrinopathy in mice. Arthritis Rheum. (2007) 56:2211-5. doi: 10.1002/art.22737

119. Doria A, Iaccarino L, Sarzi-Puttini P, Ghirardello A, Zampieri S, Arienti S, et al. Estrogens in pregnancy and systemic lupus erythematosus. Ann N Y Acad Sci. (2006) 1069:247-56. doi: 10.1196/annals.1351.022

120. Doria A, Rinaldi S, Ermani M, Salaffi F, Iaccarino L, Ghirardello A, et al. Health-related quality of life in Italian patients with systemic lupus erythematosus. II. Role of clinical, immunological and psychological determinants. Rheumatology. (2004) 43:15806. doi: 10.1093/rheumatology/keh392

121. Elbourne KB, Keisler D, McMurray RW. Differential effects of estrogen and prolactin on autoimmune disease in the NZB/NZW F1 mouse model of systemic lupus erythematosus. Lupus. (1998) 7:420-7. doi: 10.1191/096120398678920352

122. Hughes GC, Choubey D. Modulation of autoimmune rheumatic diseases by oestrogen and progesterone. Nat Rev Rheumatol. (2014) 10:74051. doi: $10.1038 /$ nrrheum.2014.144

123. Roubinian JR, Talal N, Greenspan JS, Goodman JR, Siiteri PK. Effect of castration and sex hormone treatment on survival, anti-nucleic acid antibodies, and glomerulonephritis in NZB/NZW F1 mice. J Exp Med. (1978) 147:1568.83. doi: 10.1084/jem.147.6.1568

124. Yaniv G, Twig G, Shor DBA, Furer A, Sherer Y, Mozes O, et al. A volcanic explosion of autoantibodies in systemic lupus erythematosus: a diversity of 180 different antibodies found in SLE patients. Autoimmun Rev. (2015) 14:75-9. doi: 10.1016/j.autrev.2014.10.003

125. Goldblatt F, O'Neill SG. Clinical aspects of autoimmune rheumatic diseases. Lancet. (2013) 382:797-808. doi: 10.1016/S0140-6736(13)61499-3

126. Maymon R, Cuckle H, Sehmi IK, Herman A, Sherman D. Maternal serum human chorionic gonadotrophin levels in systemic lupus erythematosus and antiphospholipid syndrome. Prenat Diagn. (2001) 21:143-5.

127. Moncayo R, Moncayo HE. A new endocrinological and immunological syndrome in SLE: Elevation of human chorionic gonadotropin and of antibodies directed against ovary and endometrium antigens. Lupus. (1995) 4:39-45. doi: 10.1177/096120339500400109

128. Ben-Chetrit A, Ben-Chetrit E. Systemic lupus erythematosus induced by ovulation induction treatment. Arthritis Rheum. (1994) 37:16147. doi: 10.1002/art.1780371109

129. De A, Sachdeva R, Bose A, Malik M, Jayachandran N, Pal R. Human Chorionic Gonadotropin influences systemic autoimmune responses. Front Endocrinol. (2018) 9:742. doi: 10.3389/fendo.2018.00742

130. Shen P, Roch T, Lampropoulou V, O'Connor RA, Stervbo U, Hilgenberg E, et al. IL-35-producing B cells are critical regulators of immunity during autoimmune and infectious diseases. Nature. (2014) 507:36670. doi: 10.1038/nature12979

131. Wang RX, Yu CR, Dambuza IM, Mahdi RM, Dolinska MB, Sergeev Y V., et al. Interleukin-35 induces regulatory B cells that suppress autoimmune disease. Nat Med. (2014) 20:633-41. doi: 10.1038/nm.3554

132. Jensen F, Muzzio D, Soldati R, Fest S, Zenclussen AC. Regulatory b10 cells restore pregnancy tolerance in a mouse model1. Biol Reprod. (2013) 89:90. doi: 10.1095/biolreprod.113.110791

133. Rolle L, Memarzadeh Tehran M, Morell-García A, Raeva Y, Schumacher A, Hartig R, et al. Cutting edge: il-10-producing regulatory b cells in early human pregnancy. Am J Reprod Immunol. (2013) 70:44853. doi: $10.1111 /$ aji.12157

134. Liu J, Chen X, Hao S, Zhao H, Pang L, Wang L, et al. Human chorionic gonadotropin and IL-35 contribute to the maintenance of peripheral immune tolerance during pregnancy through mediating the generation of $\mathrm{IL}-10^{+}$or $\mathrm{IL}-35^{+}$Breg cells. Exp Cell Res. (2019) 383:111513. doi: 10.1016/j.yexcr.2019.111513

135. Muzzio D, Zygmunt M, Jensen F. The role of pregnancy-associated hormones in the development and function of regulatory B cells. Front Endocrinol. (2014) 5:39. doi: 10.3389/fendo.2014.00039 
136. Schumacher A, Costa SD, Zenclussen AC. Endocrine factors modulating immune responses in pregnancy. Front Immunol. (2014) 5:196. doi: 10.3389/fimmu.2014.00196

137. Jensen F, Wallukat G, Herse F, Budner O, El-Mousleh T, Costa SD, et al. CD19 ${ }^{+} \mathrm{CD}^{+}$cells as indicators of preeclampsia. Hypertension. (2012) 59:861-8. doi: 10.1161/HYPERTENSIONAHA.111.188276

138. Orvieto R. Prediction of ovarian hyperstimulation syndrome: Challenging the estradiol mythos. Hum Reprod. (2003) 18:6657. doi: 10.1093/humrep/deg166

139. Neulen J, Yan Z, Raczek S, Weindel K, Keck C, Weich HA, et al. Human chorionic gonadotropin-dependent expression of vascular endothelial growth factor/vascular permeability factor in human granulosa cells: Importance in ovarian hyperstimulation syndrome. J Clin Endocrinol Metab. (1995) 80:1967:71. doi: 10.1210/jcem.80.6.7775647

140. Choudhury KM. Value of serum $\beta$-hCG in pathogenesis of pre-eclampsia. $J$ Clin Gynecol Obstet. (2012) 1:71-75. doi: 10.4021/jcgo57w

141. Pabinger I, Grafenhofer H, Kaider A, Ilic A, Eichinger S, Quehenberger $\mathrm{P}$, et al. Preeclampsia and fetal loss in women with a history of venous thromboembolism. Arterioscler Thromb Vasc Biol. (2001) 21:8749. doi: 10.1161/01.ATV.21.5.874

142. Xia Y, Kellems RE. Is preeclampsia an autoimmune disease? Clin Immunol. (2009) 133:1-12. doi: 10.1016/j.clim.2009.05.004

143. Ueno A, Cho S, Cheng L, Wang J, Hou S, Nakano H, et al. Transient upregulation of indoleamine 2,3-dioxygenase in dendritic cells by human chorionic gonadotropin downregulates autoimmune diabetes. Diabetes. (2007) 56:1686-93. doi: 10.2337/db06-1727

144. Muller V, Ob'edkova K, Krikheli I, Kogan I, Fedorova I, Lesik E, et al. Successful pregnancy outcome in women with recurrent IVF failure and Anti-hCG Autoimmunity: A report of three cases. Case Reports Immunol. (2016) 2016:1-5. doi: 10.1155/2016/4391537

145. Amato F, Warnes GM, Kirby CA, Norman RJ. Infertility Caused by hCG Autoantibody. J Clin Endocrinol Metab. (2002) 87:993-7. doi: 10.1210/jcem.87.3.8334

146. Talwar GP, Gupta JC, Nand KN, Thapa R, Mehta M. Making of vaccines against human chorionic gonadotrophin for control of fertility of women without impairment of ovulation and menstrual regularity. Reprod Immunol Open Access. (2016) 1:1-5. doi: 10.21767/2476-1974.100004

147. Hearn JP, Hodges JK, Gems S. Early secretion of chorionic gonadotrophin by marmoset embryos in vivo and in vitro. J Endocrinol. (1988) 119:24955. doi: $10.1677 /$ joe. 0.1190249

148. Thanavala YM, Hearn JP, Hay FC, Hulme M. Characterisation of the immunological response in marmoset monkeys immunised against hCG $\beta$-subunit and its relationship with their subsequent fertility. J Reprod Immunol. (1979) 1:263-73. doi: 10.1016/0165-0378(79)90006-8

149. Talwar GP. Making of a vaccine preventing pregnancy without impairment of ovulation and derangement of menstrual regularity and bleeding profiles. Contraception. (2013) 87:280-7. doi: 10.1016/j.contraception.2012.08.033

150. Simon A, Laufer N. Repeated implantation failure: Clinical approach. Fertil Steril. (2012) 97:1039-43. doi: 10.1016/j.fertnstert.2012.03.010

151. Li S, Wang J, Cheng $\mathrm{Y}$, Zhou $\mathrm{D}$, Yin $\mathrm{T}, \mathrm{Xu} \mathrm{W}$, et al. Intrauterine administration of hCG-activated autologous human peripheral blood mononuclear cells (PBMC) promotes live birth rates in frozen/thawed embryo transfer cycles of patients with repeated implantation failure. $J$ Reprod Immunol. (2017) 119:15-22. doi: 10.1016/j.jri.2016.11.006

152. Yu N, Zhang B, Xu M, Wang S, Liu R, Wu J, et al. Intrauterine administration of autologous peripheral blood mononuclear cells (PBMCs) activated by HCG improves the implantation and pregnancy rates in patients with repeated implantation failure: a prospective randomized study. Am J Reprod Immunol. (2016) 76:212-6. doi: 10.1111/aji.12542

153. Craciunas L, Tsampras N, Raine-Fenning N, Coomarasamy A. Intrauterine administration of human chorionic gonadotropin (hCG) for subfertile women undergoing assisted reproduction. Cochrane Database Syst Rev. (2018) 10:CD11537. doi: 10.1002/14651858.CD011537.pub3

154. Hong KH, Forman EJ, Werner MD, Upham KM, Gumeny CL, Winslow AD, et al. Endometrial infusion of human chorionic gonadotropin at the time of blastocyst embryo transfer does not impact clinical outcomes. Fertil Steril. (2014) 102:1591-5.e2. doi: 10.1016/j.fertnstert.2014.08.006
155. Diao LH, Li GG, Zhu YC, Tu WW, Huang CY, Lian RC, et al. Human chorionic gonadotropin potentially affects pregnancy outcome in women with recurrent implantation failure by regulating the homing preference of regulatory $\mathrm{T}$ cells. Am J Reprod Immunol. (2017) 77:e12618. doi: 10.1111/aji.12618

156. Xie H, Zeng H, He D, Liu N. Effect of intrauterine perfusion of human chorionic gonadotropin before embryo transfer after two or more implantation failures: A systematic review and meta-analysis. Eur J Obstet Gynecol. (2019) 243:133-8. doi: 10.1016/j.ejogrb.2019. 10.039

157. Gao M, Jiang X, Li B, Li L, Duan M, Sc M. Intrauterine injection of human chorionic gonadotropin before embryo transfer can improve in vitro fertilization-embryo transfer outcomes : a metaanalysis of randomized controlled trials. Fertil Steril. (2019) 112:89-97.e1. doi: 10.1016/j.fertnstert.2019.02.027

158. Santibañez Á, García J, Pashkova O, Colín O, Castellanos G, Sánchez AP, et al. Effect of intrauterine injection of human chorionic gonadotropin before embryo transfer on clinical pregnancy rates from in vitro fertilisation cycles: a prospective study. Reprod Biol Endocrinol. (2014) 12:9. doi: 10.1186/1477-7827-12-9

159. Rashidi M, Aaleyasin A, Aghahosseini M, Loloi S, Kokab A, Najmi Z. Advantages of recombinant follicle-stimulating hormone over human menopausal gonadotropin for ovarian stimulation in intrauterine insemination: A randomized clinical trial in unexplained infertility. Eur J Obstet Gynecol Reprod Biol. (2013) 169:244-7. doi: 10.1016/j.ejogrb.2013.03.002

160. Navali N, Gassemzadeh A, Farzadi L, Abdollahi S, Nouri M, Hamdi K, et al. Intrauterine administration of hCG immediately after oocyte retrieval and the outcome of ICSI: A randomized controlled trial. Hum Reprod. (2016) 31:2520-26. doi: 10.1093/humrep/dew236

161. Zarei A, Parsanezhad ME, Younesi M, Alborzi S, Zolghadri J, Samsami $A$, et al. Intrauterine administration of recombinant human chorionic gonadotropin before embryo transfer on outcome of in vitro fertilization/ intracytoplasmic sperm injection: a randomized clinical trial. Iran J Reprod Med. (2014) 12:1-6.

162. Hafezi M, Madani T, Arabipoor A, Zolfaghari Z, Sadeghi M, Ramezanali F. The effect of intrauterine human chorionic gonadotropin flushing on live birth rate after vitrified-warmed embryo transfer in programmed cycles: a randomized clinical trial. Arch Gynecol Obstet. (2018) 297:15716. doi: 10.1007/s00404-018-4752-2

163. Wirleitner B, Schuff M, Vanderzwalmen P, Stecher A, Okhowat J, Hradecký $\mathrm{L}$, et al. Intrauterine administration of human chorionic gonadotropin does not improve pregnancy and life birth rates independently of blastocyst quality: a randomised prospective study. Reprod Biol Endocrinol. (2015) 13:70. doi: 10.1186/s12958-015-0069-1

164. Liu X, Ma D, Wang W, Qu Q, Zhang N, Wang X, et al. Intrauterine administration of human chorionic gonadotropin improves the live birth rates of patients with repeated implantation failure in frozen-thawed blastocyst transfer cycles by increasing the percentage of peripheral regulatory $\mathrm{T}$ cells. Arch Gynecol Obstet. (2019) 299:1165-72. doi: 10.1007/s00404-01905047-6

165. Strug MR, Su R, Young JE, Dodds WG, Shavell VI, Dyíaz-Gimeno P, et al. Intrauterine human chorionic gonadotropin infusion in oocyte donors promotes endometrial synchrony and induction of early decidual markers for stromal survival: A randomized clinical trial. Hum Reprod. (2016) 31:1552-61. doi: 10.1093/humrep/dew080

166. Fazleabas AT, Donnelly KM, Srinivasan S, Fortman JD, Miller JB. Modulation of the baboon (Papio anubis) uterine endometrium by chorionic gonadotrophin during the period of uterine receptivity. Proc Natl Acad Sci USA. (1999) 96:2543-8. doi: 10.1073/pnas.96.5.2543

167. Uchida H, Maruyama T, Nishikawa-Uchida S, Miyazaki K, Masuda H, Yoshimura Y. Glycodelin in reproduction. Reprod Med Biol. (2013) 12:7984. doi: 10.1007/s12522-013-0144-2

168. Lee C-L, Lam KKW, Vijayan M, Koistinen H, Seppala M, Ng EHY, et al. The pleiotropic effect of Glycodelin-A in early pregnancy. Am J Reprod Immunol. (2016) 75:290-7. doi: 10.1111/aji.12471 
169. Scholz C, Toth B, Brunnhuber R, Rampf E, Weissenbacher T, Santoso $\mathrm{L}$, et al. Glycodelin a induces a tolerogenic phenotype in monocytederived dendritic cells in vitro. Am J Reprod Immunol. (2008) 60:50112. doi: 10.1111/j.1600-0897.2008.00647.x

170. Bielfeld AP, Pour SJ, Poschmann G, Stühler K, Krüssel JS, Baston-Büst DM. A proteome approach reveals differences between fertile women and patients with repeated implantation failure on endometrial level ${ }^{-}$Does hCG render the endometrium of RIF patients? Int J Mol Sci. (2019) 20:E425. doi: 10.3390/ijms20020425

171. Xiaomin Huang, Yunni Cai, Min Ding, Bo Zheng HS, Zhou J. Human chorionic gonadotropin promotes recruitment of regulatory $\mathrm{T}$ cells in endometrium by inducing chemokine CCL2. J Reprod Immunol. (2019) 137:102856. doi: 10.1016/j.jri.2019.102856

172. Puget C, Joueidi Y, Bauville E, Laviolle B, Bendavid C, Lavoué V, et al. Serial hCG and progesterone levels to predict early pregnancy outcomes in pregnancies of uncertain viability: a prospective study. Eur J Obstet Gynecol Reprod Biol. (2018) 220:100-5. doi: 10.1016/j.ejogrb.2017.11.020

173. Kim YJ, Shin JH, Hur JY, Kim H, Ku SY, Suh CS. Predictive value of serum progesterone level on $\beta$-hCG check day in women with previous repeated miscarriages after in vitro fertilization. PLoS ONE. (2017) 12:e0181229. doi: 10.1371/journal.pone.0181229

174. Brady PC, Farland LV, Racowsky C, Ginsburg E. Hyperglycosylated human chorionic gonadotropin (HCG-H) as a novel predictor of ongoing pregnancy. Fertil Steril. (2018) 110:e267-8. doi: 10.1016/j.fertnstert.2018. 07.760

175. Pillai RN, Konje JC, Tincello DG, Potdar N. Role of serum biomarkers in the prediction of outcome in women with threatened miscarriage: a systematic review and diagnostic accuracy meta-analysis. Hum Reprod Update. (2016) 22:228-39. doi: 10.1093/humupd/dmv054
176. Morley LC, Simpson N, Tang T. Human chorionic gonadotrophin (hCG) for preventing miscarriage. Cochrane Database Syst Rev. (2013) 13:CD008611. doi: 10.1002/14651858.CD008611.pub2

177. Jayasena CN, Abbara A, Izzi-Engbeaya C, Comninos AN, Harvey RA, Gonzalez Maffe J, et al. Reduced levels of plasma kisspeptin during the antenatal booking visit are associated with increased risk of miscarriage. J Clin Endocrinol Metab. (2014) 99:E2652-60. doi: 10.1210/jc.20 14-1953

178. Freis A, Schlegel J, Daniel V, Jauckus J, Strowitzki T, Germeyer A. Cytokines in relation to hCG are significantly altered in asymptomatic women with miscarriage - a pilot study. Reprod Biol Endocrinol. (2018) 16:17. doi: 10.1186/s12958-018-0411-5

179. Sha J, Liu F, Zhai J, Liu X, Zhang Q, Zhang B. Alteration of Th17 and Foxp3 ${ }^{+}$regulatory $\mathrm{T}$ cells in patients with unexplained recurrent spontaneous abortion before and after the therapy of hCG combined with immunoglobulin. Exp Ther Med. (2017) 14:1114-1118. doi: 10.3892/etm.2017.4574

Conflict of Interest: The authors declare that the research was conducted in the absence of any commercial or financial relationships that could be construed as a potential conflict of interest.

Copyright (C) 2020 Gridelet, Perrier d'Hauterive, Polese, Foidart, Nisolle and Geenen. This is an open-access article distributed under the terms of the Creative Commons Attribution License (CC BY). The use, distribution or reproduction in other forums is permitted, provided the original author(s) and the copyright owner(s) are credited and that the original publication in this journal is cited, in accordance with accepted academic practice. No use, distribution or reproduction is permitted which does not comply with these terms. 